\title{
Synthesis, Characterization and Microbial Activity of Chiral Mixed Ligand Transition Metal Complexes
}

\author{
${ }^{1}$ V. S. Shivankar, ${ }^{2}$ Y. A. Gaikwad, ${ }^{3}$ H. U. Mulla, ${ }^{4}$ R.J.Patil, ${ }^{5}$ L. V. Gavali \\ Department of Chemistry, Karmaveer Bhaurao Patil College, Vashi, Navi Mumbai (Maharashtra) - 400 703, \\ India.
}

\begin{abstract}
Chiral mixed ligand (CML) metal complexes are synthesized by using isonitrosopropiophenone (HINPP) as a primary ligand and saccharides such as (+)-glucose and/or (-)-fructose as a chiral secondary ligand. The metal complexes have been characterized by elemental analysis and various physico-chemical techniques such as molar conductance, magnetic susceptibility, electronic absorption, infrared spectral studies and thermal analysis. Room temperature magnetic susceptibility measurements of these complexes are indicative of a tetrahedral and/or octahedral geometry. The molar conductance studies of the complexes indicate their non-electrolytic nature. Electronic absorption/reflectance spectra of the complexes show intraligand, charge transfer, and the d-d transitions, consistent with their proposed geometry. Thermal studies show the presence of lattice water in the complexes. The specific rotation of the complexes is due to the corresponding chiral saccharide moiety.

The Paper Disc Diffusion method has been used to study the antibacterial activity of the compounds against some of the pathogenic bacteria such as C. diphtheriae, E. coli, S. typhi, S. dysenteriae, S. aureus and $V$. cholerae. The antifungal activity of the complexes against some of the pathogenic fungi such as Candida albicans and Aspergillus niger has been studied by tube dilution method. The results have been compared against those of controls, which were screened simultaneously. The complexes have been screened for acute oral toxicity in albino rats.
\end{abstract}

Key words: Mixed ligand, metal complexes, isonitrosopropiophenone, (+)-glucose and (-)-fructose

\section{Introduction}

In recent years, there has been renewed interest in the synthesis and study of mixed ligand transition metal complexes. The utility aspects of these complexes have received their share of attention as these have found applications in diverse fields. Chiral metal complexes are well known for their use as catalysts, especially in asymmetric synthesis ${ }^{1-3}$, asymmetric epoxidations or Sharpless epoxidations ${ }^{4}$ and resolution of racemic compounds ${ }^{5}$. Light catalyzed inversion and diastereoisomeric equilibration ${ }^{6}$ in chiral metal complexes have been studied extensively.

Some metal ligand complexes are found to catalyze reactions such as oxidation, oxidative cleavage, hydroformylation, etc. and have shown catalyse like activity in decomposition of hydrogen peroxide. It is well established ${ }^{7}$ that ternary complexes play a decisive role in the activation of enzymes and also in the storage and transport of active substances. The binary and ternary transition metal complexes have shown biological activity $^{8}$. Mixed ligand complexes of transition metals are commonly found in biological systems. During recent years metal complexes of some N-/O- donor ligands have attracted considerable attention because of their greater antifungal and antibacterial activities than those of the parent ligands ${ }^{9}$. Ternary complexes containing an amino acid as a secondary ligand are of significance as they are potential models for enzyme-metal ion substrate complexes.

The present work comprises of synthesis and characterization of chiral mixed ligand $\mathrm{Co}(\mathrm{II}) / \mathrm{Ni}(\mathrm{II})$ complexes prepared by using HINPP as a primary ligand (HL) and various chiral saccharides as secondary ligands (HL'). The mixed ligand metal complexes have been characterized on the basis of elemental analysis, electrical conductance, room temperature magnetic susceptibility measurements, spectral and thermal studies. Probable structures have been suggested for the mixed ligand complexes on the basis of the results of elemental analysis and various physico-chemical studies.

These complexes have been studied for its microbial activites. The Paper Disc Diffusion method has been used to study the antibacterial activity of the compounds against some of the pathogenic bacteria such as C. diphtheriae, E. coli, S. typhi, S. dysenteriae, S. aureus and V. cholerae. The antifungal activity of the complexes against some of the pathogenic fungi such as Candida albicans and Aspergillus niger has been studied by tube dilution method. 
Materials

\section{Experimental}

Analytical grade cobalt(II) chloride hexahydrate and nickel(II) chloride hexahydrate were used as received without further purification. Chiral saccharides were obtained from E. Merck. saccharide was obtained from S. D. Fine Chemicals, Mumbai, India. Ethanol, methanol and chloroform used as solvents were purified and dried according to standard procedure ${ }^{10}$. N,N-Dimethyl formamide was obtained from E. Merck and used without further purification. The bacterial and fungal subcultures were obtained from the Haffkine Institute, Mumbai.

\section{Methods}

Isonitrosopropiophenone (HINPP) was prepared according to the reported procedure ${ }^{11}$.

\section{Preparation of chiral mixed ligand (CML) complexes using chiral saccharides}

CML Co(II) and Ni(II) complexes were prepared from cobalt(II) chloride hexahydrate /nickel(II) chloride hexahydrate, Isonitrosopropiophenone (HINPP) and chiral secondary ligands (HL') such as (+)-glucose (Dextrose) and (-)-fructose.

To a blue-colored ethanol solution of cobalt(II) chloride hexahydrate (237 mg, $1 \mathrm{mmol}$ ), was added an ethanol solution of HINPP (163 mg, $1 \mathrm{mmol}$ ). The mixture was stirred and kept in a boiling water bath for 10 minutes. To this was added an aqueous solution of the saccharides $(1 \mathrm{mmol})$. This mixture $(1: 1: 1 \mathrm{molar}$ proportion) was heated in a hot water bath till the temperature reached $50^{\circ} \mathrm{C}$. The complexes precipitated by raising the $\mathrm{pH}$ of the reaction mixture. The mixture was cooled and the solid was filtered, washed with ice-cold water followed by 1:1 ethanol : water. The complexes thus prepared were dried under vacuum. The complexes with nickel(II) chloride hexahydrate were prepared by the same method reported above.

\section{Instrumentation}

The complexes were analyzed for the metal contents, $\mathrm{C}, \mathrm{H}$ and $\mathrm{N}$ using standard procedures. For the determination of metal content determined by complexometric EDTA titration ${ }^{12}$. The nitrogen content of the complexes was determined by Kjeldahl's method ${ }^{13}$. Analyses for carbon and hydrogen were carried out at the Microanalytical Laboratory, University Department of Chemical Technology, Mumbai.

The molar conductance values were measured in methanol at the range of $10^{-3} \mathrm{M}$ concentration on a model CM-180 Elico digital conductivity meter with a dip-type conductivity cell fitted with a platinum electrode (cell constant $=1.0 \mathrm{~cm}^{-1}$ ). Room temperature magnetic susceptibilities were measured by a Guoy balance using $\mathrm{Hg}\left[\mathrm{Co}(\mathrm{SCN})_{4}\right]$ as the calibrant. Effective magnetic moments were calculated after applying diamagnetic corrections for the ligand components using Pascal's constants ${ }^{14}$.

The specific optical rotation values for the complexes were determined in methanol solution $(0.01 \%)$ on a Jasco DIP-140 polarimeter. Electronic absorption spectra in the ultraviolet range in methanol at $10^{-4} \mathrm{M}$ concentration were measured on a Shimadzu UV-160A spectrophotometer. Electronic spectra in the visible range in chloroform at $10^{-3} \mathrm{M}$ concentration were measured on a Spectronic-20 spectrophotometer. FTIR spectra were recorded as $\mathrm{KBr}$ discs on a model 160 Perkin-Elmer FTIR spectrophotometer.

TGA studies of the complexes were made on a Mettler TC 10A TA processor at Indian Institute of Technology, Mumbai by recording the change in weight of the complexes on increasing the temperature up to $700{ }^{\circ} \mathrm{C}$ at a heating rate of $10^{\circ} \mathrm{C} / \mathrm{min}$.

\section{Antimicrobial screening}

The minimum inhibition concentrations (MIC) of the complexes were determined by using the Paper Disc Diffusion Method described elsewhere ${ }^{15}$. Tube dilution method, described elsewhere ${ }^{16}$, was used to study antifungal activity.

\section{Paper Disc Diffusion Method}

This method was used to study the antibacterial activity of the complexes against some of the pathogenic bacteria. In this method, $0.1 \mathrm{~mL}$ of inoculums of the test organism was spread uniformly on the surface of the agar medium in a Petri plate by using a spreader. The 50, 100 and $200 \mathrm{ppm}$ solutions of the complexes were prepared, respectively, by dissolving $0.5,1$, and $2 \mathrm{mg}$ of the complex in $10 \mathrm{~mL}$ of dimethyl formamide (DMF) in a hot water bath. The sterilized Whatmann filter paper discs of $5 \mathrm{~mm}$ diameter were dipped into the solution and then were placed on the surface of the agar. Up to four discs in each plate were used. The plates were incubated at $37{ }^{\circ} \mathrm{C}$ for 24 hours. During incubation, the complex diffuses from the filter paper into the agar.

The activity of the complexes was assessed by measuring the diameter of the inhibited zone in millimeters (mm.). The results were compared against those of control (tetracycline), which was screened simultaneously. Solvent DMF, used as blank, was also run to know its activity.

\section{Tube Dilution Method}


This method was used to study the antifungal activity of the complexes against some of the pathogenic fungi. Fungus inoculum was prepared by inoculating the selected fungus into sterilized Sabouraud's broth to which $0.1 \mathrm{mg} / \mathrm{mL}$ of streptomycin was added to prevent bacterial contamination. After sporulation the spores were harvested in the same media by gentle stirring using a magnetic stirrer and the spore suspension was poured into another sterile flask. To a $5 \mathrm{~mL}$ of Sabouraud's broth contained in a $15 \mathrm{~mL}$ Corning test-tube, 0.1 $\mathrm{mL}$ of the test solution of the complex in DMF was added. It was autoclaved at $15 \mathrm{lb}$ pressure for 15 minutes. The tubes were then cooled and were inoculated with $0.1 \mathrm{~mL}$ spore suspension. The tubes were then kept on a rotary shaker and incubated at room temperature for 24 hours. The percentage growth of the fungus was calculated after determining the optical density (OD) of the solution on a spectrophotometer at $530 \mathrm{~nm}$ with inoculated Sabouraud's broth as blank. The growth of the fungus in the tube, which contained none of the antifungal agent, was assumed as $100 \%$. The results were compared against those of control (amphotericin), which was screened simultaneously.

\section{Acute toxicity studies}

All the test samples were prepared as suspensions by using distilled water as solvent. Acute oral toxicity study of these samples was carried out in albino rats (80-120 gms) of either sex maintained under standard husbandry conditions. Ten rats per group were used for all sets of experiments. The animals were allowed to take standard laboratory feed and water ad libitum. The animals were divided into control and test groups. The test groups received various test substances orally in different doses and they were observed for mortality till 24 hours. To all control animals $0.5 \mathrm{ml}$ of vehicle (sterile water) was given as a control. The $\mathrm{LD}_{50}$ values were determined by the method of Litchfield and Wilcoxon ${ }^{17}$.

\section{Part I. Characterization of metal complexes}

\section{Results And Discussion}

The synthesis of CML complexes may be represented as shown in equation (i):

$$
\begin{aligned}
& \mathrm{M}(\mathrm{II})+\mathrm{HL}+\mathrm{HL}^{\prime} \longrightarrow \mathrm{M}(\mathrm{II}) \mathrm{LL}^{\prime} \cdot 2 \mathrm{H}_{2} \mathrm{O}+2 \mathrm{H}^{+} \\
& 1: 1: 1 \quad \text { CML complex }
\end{aligned}
$$

(where HL is HINPP and HL' is a chiral saccharide ligand).

All of the complexes are non-hygroscopic stable solids. They are colored and thermally stable, indicating a strong metal-ligand bond. The elemental analysis data of metal complexes (Table 1) is consistent with their general formulation as mixed ligand complexes MLL' $2 \mathrm{H}_{2} \mathrm{O}$. The molar conductance values of the complexes (Table 1) in methanol at $10^{-3} \mathrm{M}$ concentration are very low $(<1)$, indicating their non-electrolytic nature $^{18}$. The specific rotation values for the complexes (Table 1) with (+)-glucose in methanol solution $(0.01 \%)$ were found to be positive. The value for the complex with (-)-fructose was found to be negative. This indicates that the specific rotation of the complexes is due to the corresponding chiral saccharide moiety.

\section{Magnetic studies}

The observed $\mu_{\text {eff }}$ values are suggestive of the tetrahedral geometry for the Co(II) complexes and an octahedral geometry for the Ni(II) complexes (Table 2).

\section{Electronic absorption spectra}

The electronic spectra of the metal complexes in methanol solution, recorded in the ultraviolet region (Fig. 1), exhibit intra-ligand and charge transfer transitions in the range around 25,940-48,192 $\mathrm{cm}^{-1}$ and near $26,000 \mathrm{~cm}^{-1}$, respectively. The electronic absorption spectra of Co(II) complexes in chloroform solution in the visible and near infrared region shows three transition bands in the region around $25,000 \mathrm{~cm}^{-1}, 16,666 \mathrm{~cm}^{-1}$ and $12,000 \mathrm{~cm}^{-1}$ respectively, while that of the $\mathrm{Ni}(\mathrm{II})$ complexes show two transition bands in the region around $25,000 \mathrm{~cm}^{-1}$ and $12,195 \mathrm{~cm}^{-1}$, respectively .

The diffuse reflectance spectra of $\mathrm{Co}$ (II) complexes show the d-d transition bands (Table 2) in the region around 12,900 and 17,500 $\mathrm{cm}^{-1}$, which are assigned to transitions ${ }^{4} \mathrm{~A}_{2}(\mathrm{~F}) \rightarrow{ }^{4} \mathrm{~T}_{1}(\mathrm{~F})\left(\mathrm{v}_{2}\right)$ and ${ }^{4} \mathrm{~A}_{2}(\mathrm{~F}) \rightarrow$ ${ }^{4} \mathrm{~T}_{1}(\mathrm{P})\left(\mathrm{v}_{3}\right)$, respectively. The Ni(II) complexes show two transition bands (Table 2$)$ in the region around 12,700 and $18,900 \mathrm{~cm}^{-1}$, which are ascribed to transitions ${ }^{3} \mathrm{~A}_{2 \mathrm{~g}}(\mathrm{~F}) \rightarrow{ }^{3} \mathrm{~T}_{1 \mathrm{~g}}(\mathrm{~F})\left(\mathrm{v}_{2}\right)$ and ${ }^{3} \mathrm{~A}_{2 \mathrm{~g}}(\mathrm{~F}) \rightarrow{ }^{3} \mathrm{~T}_{1 \mathrm{~g}}(\mathrm{P})\left(v_{3}\right)$, respectively. As the $v_{1}$ band occurs at low energy, usually in the range not accessible due to instrumental limitations, it is not observed in the present cases. 


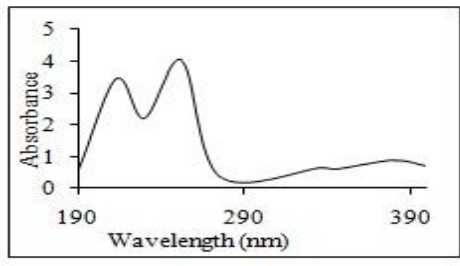

(A)

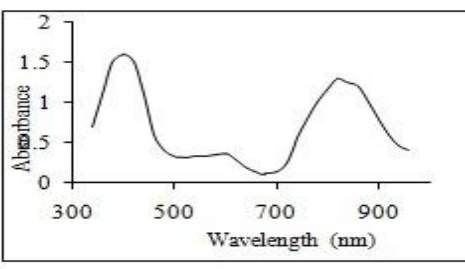

(B)

Fig. 1. (A) Ultraviolet spectra of $[\mathrm{Co}(\mathrm{L})(\mathrm{Dex})] \cdot 2 \mathrm{H}_{2} \mathrm{O}$ in methanol solution

(B) Visible spectra of $[\mathrm{Co}(\mathrm{L})($ Dex $)] \cdot 2 \mathrm{H}_{2} \mathrm{O}$ in Chloroform solution.

The parameter B, which measures Racah inter electronic repulsion, is usually lower in a complex than in the free ion (and is usually referred to as $\mathrm{B}^{\prime}$ ), which is an indication of orbital overlap and delocalisation of $\mathrm{d}$ orbitals.

The value of $\mathrm{B}$ for free $\mathrm{Co}(\mathrm{II})$ ion is $971 \mathrm{~cm}^{-1}$. The present $\beta$ values are less than unity, suggesting an appreciable covalent character of the $\mathrm{M}-\mathrm{O}$ bond. The observed spectral features of all the $\mathrm{Co}$ (II) complexes are, therefore, in conformity with the tetrahedral geometry proposed on the basis of their analytical data and observed magnetic moments .

For many octahedral $\mathrm{Ni}$ (II) complexes, the ratio $v_{2} / v_{1}$ is found to be in the range 1.6-1.8. with the present $\mathrm{Ni}$ (II) complexes this ratio lies around 1.84. the value of $\mathrm{Dq}$ for the complexes are in the range 687-690 $\mathrm{cm}^{-1}$, which lies well within the range reported for octahedral $\mathrm{Ni}(\mathrm{II})$ complexes $\left(640-1270 \mathrm{~cm}^{-1}\right)$. The B' values for octahedral complexes under investigation are in the range $726-729 \mathrm{~cm}^{-1}$, which is less than the value of 1041 $\mathrm{cm}^{-1}$ found in the free ion ${ }^{19}$, indicating that the free ion value is reduced considerably, suggesting appreciable orbital overlap.

\section{Infra-red spectra}

The FT-IR spectra of the CML metal complexes were recorded as $\mathrm{KBr}$ discs .Some of the important bands have been assigned (Table 3 ).

1. A broad band observed in the region between $3325-3318 \mathrm{~cm}^{-1}$ due to asymmetric and symmetric $\mathrm{O}-\mathrm{H}$ stretching modes and a strong peak in the range $1574-1572 \mathrm{~cm}^{-1}$ due to $\mathrm{H}-\mathrm{O}-\mathrm{H}$ bending showing the presence of water of crystallization ${ }^{20}$.

2. An important feature of the IR spectra of the complexes is the absence of band due to O-H stretching vibrations of $=\mathrm{N}-\mathrm{OH}$ group of HINPP indicating the complex formation takes place by deprotonation of the oxime of HINPP. The $v(\mathrm{C}=\mathrm{O})$ region of IR spectra of complexes shows a strong band in the region 1595$1600 \mathrm{~cm}^{-1}$ due to $\mathrm{C}=\mathrm{O}$ stretching vibrations of the coordinated carbonyl group of HINPP. The shift of $v(\mathrm{C}=\mathrm{O})$ of HINPP towards lower wave number from its position at $1660 \mathrm{~cm}^{-1}$ in free $\mathrm{HINPP}^{7}$ suggests the involvement of carbonyl group of the ligand in bonding to the metal ion. The $\mathrm{C}=\mathrm{N}$ stretching frequency observed at $1593 \mathrm{~cm}^{-1}$ in the spectrum of HINPP is found to be shifted to the range $1495-1515 \mathrm{~cm}^{-1}$ in the spectra of the complexes, indicating coordination through the $\mathrm{N}$ donor atom of the HINPP ${ }^{21}$ group. A new medium intensity band, attributed to $v(\mathrm{~N} \rightarrow \mathrm{O})$, observed in the range $1180-1203 \mathrm{~cm}^{-1}$ in the spectra of the complexes, further supports above observation.

3. The merging and broadening of bands was found to be a common feature of transition metal-saccharide complexes. The spectra of all the complexes with saccharides showed broad bands in the $\mathrm{O}-\mathrm{H}$ and $\mathrm{C}-\mathrm{H}$ regions, indicating a merging of individual bands. The spectral characteristics are similar to those observed with other $1^{\text {st }}$ row transition metal complexes. The structural vibrations of the intermolecular hydrogen bonded $\mathrm{O}-\mathrm{H}$ groups of the free saccharides were affected ionization and exhibited a broad but nearly symmetrical band at $\sim 3400 \mathrm{~cm}^{-1}$. The strongly coupled ring vibrational frequencies for bending modes $\mathrm{COH}, \mathrm{CH}_{2}$ and $\mathrm{CCH}$ of the free saccharides (1460-1340 $\mathrm{cm}^{-1}$ ) showed merging at $1400 \mathrm{~cm}^{-1}$ upon complex formation. Similarly, the C-O and C-C stretching vibrations in the region $1140-990 \mathrm{~cm}^{-1}$ were also merged at $\sim 1050 \mathrm{~cm}^{-1}$ upon complex formation, in contrast to the sharp bands observed for the free saccharides and other metal-saccharide adducts. The anomeric region $\left(950-500 \mathrm{~cm}^{-1}\right)$ showed very weak marker bands of mostly $\alpha$-anomer. It was clear from the spectra that the saccharides were involved in coordination through some deprotonated $-\mathrm{OH}$ groups as observed from the broad bands in $v(\mathrm{O}-\mathrm{H})$ region, $3500-3200 \mathrm{~cm}^{-1}$. On the basis of coordinating abilities of the various saccharides reported, a 3,4-trans-diol arrangement has been proposed for CML complexes with glucose and fructose.

4. The C-O and C-C stretching vibrations in the region $1140-990 \mathrm{~cm}^{-1}$ were also merged at $\sim 1050 \mathrm{~cm}^{-1}$ upon complex formation, in contrast to the sharp bands observed for the free saccharides and other metalsaccharide adducts. The new bands of weak intensity, observed in the regions about $648-595 \mathrm{~cm}^{-1}$ and $465-420 \mathrm{~cm}^{-1}$, may be ascribed to M-N and M-O vibrations, respectively. 


\section{Thermo gravimetric and $\mathrm{X}$-ray analysis}

The thermograms (TG) of the complexes have been recorded in flowing nitrogen atmosphere at the heating rate of $10^{\circ} \mathrm{C} / \mathrm{min}$ on approximately $10 \mathrm{mg}$ samples. All the complexes investigated show similar behavior in their TG and Differential Thermal Analysis (DTA) studies. The DTA curve has been recorded in static air. The complexes display an endothermic peak at $99^{\circ} \mathrm{C}$, which is attributed to the release of a water molecule. X-ray and chemical analysis showed that the final product of the decomposition process was $\mathrm{CoO}$, left as residue representing $21.6 \%$ of the initial mass of the complex. This indicates that the metal powder produced in the decomposition process was too reactive and transforms to metal oxide spontaneously even in the presence of traces of oxygen present in the nitrogen gas used in the experiment or that produced due to disproportionation reaction during the decomposition. Probable structures have been determined for mixed ligand complexes on the basis of results of elemental analysis and various physicochemical studies. (Fig.2)

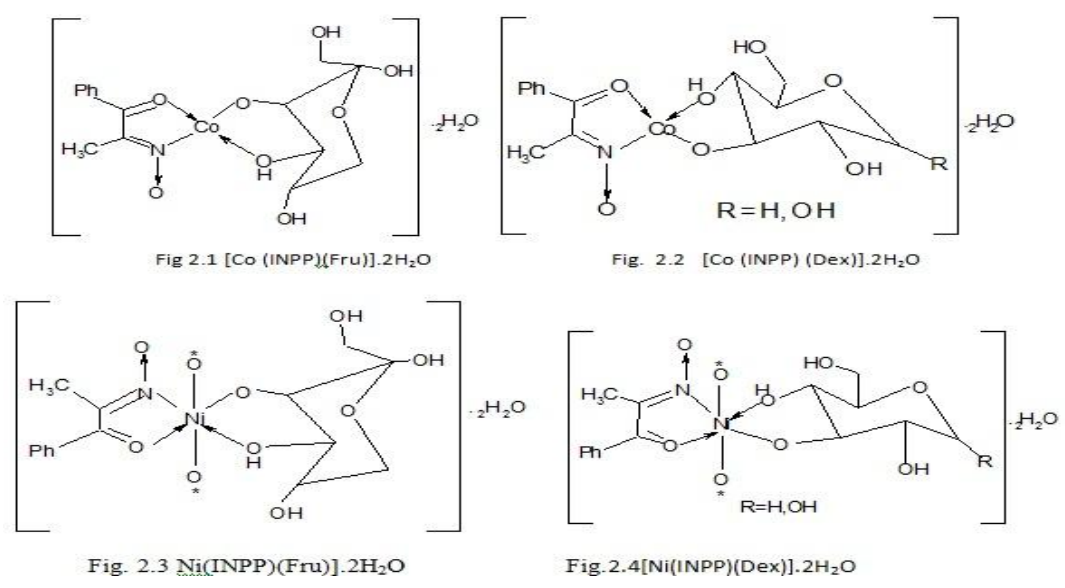

\section{Part III. Biological Activities}

It has been found that the metal complexes with HINPP or saccharides possessing biological activities $^{22-23}$. The antibacterial and antifungal activities of the ligands and the complexes have been studied against some of the pathogenic bacteria and fungi. The paper disc diffusion method has been used to study the antibacterial activity against $C$. diphtheriae, E. coli, S. typhi, S. dysenteriae, S. aureus and V. cholerae. The antibacterial activity data of metal salt and standard antibacterial compound tetracycline is compared. It has been observed that the saccharides used for current investigation do not show antibacterial and antifungal activity at 50, 100 and $200 \mathrm{ppm}$.

The study shows enhancement of the activity of all the ligands against $V$. cholerae on complexation and hence on chelation. The CML complex with fructose shows good activity against all the organisms under study. The complexes with glucose show activity against $C$. diphtheriae and S. aureus. A bacteriostatic effect has been observed in a number of cases, which show that the complexes inhibit protein synthesis and act by binding to the ribosome ${ }^{24}$. The binding, however, is not tight, and when the concentration of the complex is lowered, the complex becomes free from the ribosome and growth is resumed.

Chelation reduces considerably the polarity of the metal ions in the complexes. This is due mainly to the partial sharing of its positive charge with the donor group and possible $\pi$-electron delocalisation over the whole chelate ring system through $\mathrm{p} \pi-\mathrm{p} \pi$ or $\mathrm{d} \pi-\mathrm{d} \pi$ interactions of the orbitals of the ligands and metal ions, which in turn increases the hydrophobic character of the chelate and thus enables its permeation through the lipid layer (cell membrane) of microorganisms. Compared to tetracycline, the present complexes are much less active against the representative strains of microorganisms.

The antifungal activity of the complexes against Candida albicans and Aspergillus niger was studied by the tube dilution method. The results have been expressed as percentage inhibition (Table 5). The data show that the antifungal activity of the metal salt as well as that of the ligands is significantly enhanced on complexation. All the complexes show moderate antifungal activity against both fungi. Generally, the complexes show more activity against Aspergillus niger than against Candida albicans. Compared to standard antifungal compound amphotericin, the present complexes are much less active.

\section{Acute toxicity}

Acute toxicity gives the rapid indication of the potential hazard and indicates the class of toxicity to which a chemical belongs. One of the basic tests for determining the relative acute toxicity in the animals is to find out $\mathrm{LD}_{50}$. Acute oral toxicity studies on the CML complexes were carried out in albino rats. The patterns of symptoms found for both the compounds were similar but varied in degree and intensity with doses. The 
symptoms observed in animals after administering the different doses were excitation, respiratory disturbances, tremors, convulsions and death. The $\mathrm{LD}_{50}$ values are recorded in Table 6.

As compared to $\mathrm{Co}(\mathrm{II})$ chloride $\left(\mathrm{LD}_{50}\right.$ value $\left.=766 \mathrm{mg} / \mathrm{kg}\right)$ and $\mathrm{Ni}(\mathrm{II})$ chloride $(105 \mathrm{mg} / \mathrm{kg})$ the $\mathrm{CML}$ cobalt/nickel complexes show higher values, indicating the increase in $\mathrm{LD}_{50}$ value due to complexation. The results suggest that the complexes are moderately toxic. Compared to the standard compound, the present complexes show more toxicity.

\section{Conclusions}

Based on the above discussion and information available in the literature, the following conclusions may be drawn.

1. Higher decomposition temperature and electrical conductance studies show the presence of strong metalligand bonding and non-electrolytic nature of the complexes, respectively.

2. Specific rotation measurement studies are indicative of the chirality of the complexes.

3. Magnetic studies are indicative of tetrahedral geometry for $\mathrm{Co}(\mathrm{II})$ complexes and octahedral geometry for $\mathrm{Ni}$ (II) complex, which is confirmed by crystal field transitions shown by the electronic spectra.

4. IR spectra show bonding of the metal ion through $\mathrm{N} / \mathrm{O}$ and $\mathrm{O}$ of the two ligands and presence of water of crystallization, confirmed by thermal analysis.

5. The studies on antimicrobial activity indicate that among other factors, constitution of the ligand, its coordination to the metal ion, the nature of metal ion, its oxidation state in the complex and the strain of the microorganism has influence on antimicrobial activity.

6. Metal ions with low oxidation potential show more antibacterial activity. As compared to the $\mathrm{Ni}(\mathrm{II})$ complex, the mixed ligand Co(II) complexes show better antimicrobial activity against the selected strains.

7. Compared to the standard antibacterial/antifungal compound, the present complexes are much less active against the representative strains.

8. $\mathrm{LD}_{50}$ values serve to provide a convenient way to classify the chemical into toxicity classes. The results suggest that the complexes are moderately toxic.

\section{Acknowledgement}

One of the author is grateful to University Grants Commission (Western Regional Office, Pune) for the sanction of financial assistance to the minor research project.

Table 1. Colour, decomposition temperature, molar conductance, specific rotation and analytical data of the

\begin{tabular}{|c|c|c|c|c|c|c|c|c|c|}
\hline \multirow[b]{2}{*}{ Compound } & \multirow[b]{2}{*}{$\begin{array}{l}\text { Empirical } \\
\text { formula }\end{array}$} & \multirow[b]{2}{*}{ Colour } & \multirow{2}{*}{$\begin{array}{c}\text { Decom } \\
p \\
\text { Temp. } \\
\left({ }^{\circ} \mathrm{C}\right)\end{array}$} & \multicolumn{4}{|c|}{ Elemental Analysis Found (Calculated) } & \multirow{2}{*}{$\begin{array}{c}\text { Molar } \\
\text { Cond. } \\
\text { mhos.cm }{ }^{2} \\
. \text { mol }^{-1}\end{array}$} & \multirow[b]{2}{*}[\alpha]{$_{D}$} \\
\hline & & & & $\% \mathrm{M}$ & $\% \mathrm{C}$ & $\% \mathrm{~N}$ & $\% \mathrm{H}$ & & \\
\hline$[\mathrm{Co}(\mathrm{INPP})(\mathrm{Dex})] \cdot 2 \mathrm{H}_{2} \mathrm{O}$ & $\mathrm{CoC}_{15} \mathrm{H}_{21} \mathrm{O}_{9} \mathrm{~N}$ & Light yellow & 277 & $\begin{array}{r}14.22 \\
(14.10)\end{array}$ & $\begin{array}{r}42.91 \\
(43.07)\end{array}$ & $\begin{array}{l}3.52 \\
(3.35)\end{array}$ & $\begin{array}{c}5.11 \\
(5.02)\end{array}$ & 0.24 & +193.0 \\
\hline$[\mathrm{Co}(\mathrm{INPP})(\mathrm{Fru})] \cdot 2 \mathrm{H}_{2} \mathrm{O}$ & $\mathrm{CoC}_{15} \mathrm{H}_{21} \mathrm{O}_{9} \mathrm{~N}$ & Light yellow & 285 & $\begin{array}{c}14.12 \\
(14.10)\end{array}$ & $\begin{array}{r}43.00 \\
(43.07)\end{array}$ & $\begin{array}{l}3.40 \\
(3.35)\end{array}$ & $\begin{array}{l}5.27 \\
(5.02)\end{array}$ & 0.30 & -220.0 \\
\hline$[\mathrm{Ni}(\mathrm{INPP})(\mathrm{Dex})] \cdot 2 \mathrm{H}_{2} \mathrm{O}$ & $\mathrm{NiC}_{15} \mathrm{H}_{21} \mathrm{O}_{9} \mathrm{~N}$ & Green & 290 & $\begin{array}{c}14.25 \\
(14.05)\end{array}$ & $\begin{array}{r}43.01 \\
(43.09)\end{array}$ & $\begin{array}{r}3.55 \\
(3.35)\end{array}$ & $\begin{array}{l}4.89 \\
(5.02)\end{array}$ & 0.38 & +225.9 \\
\hline$[\mathrm{Ni}(\mathrm{INPP})(\mathrm{Fru})] \cdot 2 \mathrm{H}_{2} \mathrm{O}$ & $\mathrm{NiC}_{15} \mathrm{H}_{21} \mathrm{O}_{9} \mathrm{~N}$ & Green & 260 & $\begin{array}{c}14.25 \\
(14.05)\end{array}$ & $\begin{array}{r}43.01 \\
(43.09)\end{array}$ & $\begin{array}{r}3.55 \\
(3.35)\end{array}$ & $\begin{array}{l}4.89 \\
(5.02)\end{array}$ & 0.41 & -303.0 \\
\hline
\end{tabular}

a where Q represents the deprotonated primary ligand HINPP whereas Dex and Fru represent the deprotonated secondary ligands dextrose and fructose, respectively.

Table 2. Magnetic moments and diffuse reflectance spectral data $\left(\mathrm{cm}^{-1}\right)$ for $\mathrm{CML} \mathrm{Co(II)/Ni(II)} \mathrm{complexes}$

\begin{tabular}{|l|c|c|c|c|c|c|c|c|}
\hline Compound & $\begin{array}{c}\mu_{\text {eff }} \\
\text { (B.M.) }\end{array}$ & $v_{1}^{*}$ & $v_{2}$ & $v_{3}$ & Dq & $\mathrm{B}^{\prime}$ & $\beta$ & $v_{2} / v_{1}$ \\
\hline$[\mathrm{Co}(\mathrm{INPP})(\mathrm{Dex})] \cdot 2 \mathrm{H}_{2} \mathrm{O}$ & 4.54 & 6,286 & 12,953 & 17,391 & 628.6 & 765.7 & 0.788 & 2.06 \\
\hline$[\mathrm{Co}(\mathrm{INPP})(\mathrm{Fru})] \cdot 2 \mathrm{H}_{2} \mathrm{O}$ & 4.61 & 6,339 & 12,853 & 17,543 & 633.9 & 758.5 & 0.781 & 2.02 \\
\hline$[\mathrm{Ni}(\mathrm{INPP})(\mathrm{Dex})] \cdot 2 \mathrm{H}_{2} \mathrm{O}$ & 2.96 & 6,874 & 12,658 & 18,867 & 687.4 & 726.6 & 0.697 & 1.84 \\
\hline$[\mathrm{Ni}(\mathrm{INPP})(\mathrm{Fru})] \cdot 2 \mathrm{H}_{2} \mathrm{O}$ & 2.82 & 6,901 & 12,706 & 18,939 & 690.1 & 729.4 & 0.700 & 1.84 \\
\hline
\end{tabular}

* calculated value

Table 3. Some Important Infrared Spectral Bands $\left(\mathrm{cm}^{-1}\right)$ of CML Complexes ${ }^{\mathrm{a}}$ 


\begin{tabular}{|c|c|c|c|c|c|c|c|c|c|c|c|}
\hline Complex & $\begin{array}{l}v(\mathrm{O}-\mathrm{H}) \\
\text { (Sacch) }\end{array}$ & $\begin{array}{l}\mathrm{v}(\mathrm{O}-\mathrm{H}) \\
\text { (Sacch) }\end{array}$ & $\begin{array}{l}v(\mathrm{O}-\mathrm{H}) \\
\left(\mathrm{H}_{2} \mathrm{O}\right)\end{array}$ & $\begin{array}{l}v(\mathrm{C}=0) \\
(\mathrm{HINPP})\end{array}$ & $v(\mathrm{HOH})$ & $\begin{array}{c}v(\mathrm{C}=\mathrm{N}) \\
(\mathrm{HINPP} \\
)\end{array}$ & $\begin{array}{l}v(\mathrm{C}-\mathrm{OH}) \\
v\left(\mathrm{C}-\mathrm{H}_{2}\right) \\
v(\mathrm{C}-\mathrm{CH}) \\
(\mathrm{Sacch})\end{array}$ & $\begin{array}{l}v(\mathrm{~N} \rightarrow \mathrm{O}) \\
(\mathrm{HINPP})\end{array}$ & $\begin{array}{l}v(\mathrm{C}-0) \\
\mathrm{v}(\mathrm{C}-\mathrm{C}) \\
\text { (Sacch) }\end{array}$ & $v(M-N)$ & $v(M-0)$ \\
\hline$[\mathrm{Co}(\mathrm{INPP})(\mathrm{Dex})] \cdot 2 \mathrm{H}_{2} \mathrm{O}$ & $3500 \mathrm{~s}$ & $3395 \mathrm{~m}$ & $3315 \mathrm{w}$ & $1598 \mathrm{~s}$ & $1573 \mathrm{~s}$ & $1509 \mathrm{~s}$ & 1408 & 1200 & 1050 & $602^{b} \mathrm{w}$ & $420^{b} \mathrm{w}$ \\
\hline$[\mathrm{Co}(\mathrm{INPP})(\mathrm{Fru})] \cdot 2 \mathrm{H}_{2} \mathrm{O}$ & $3505 \mathrm{~m}$ & $3400 \mathrm{~s}$ & $3362 \mathrm{w}$ & $1599 \mathrm{~m}$ & $1575 \mathrm{~s}$ & $1510 \mathrm{~s}$ & 1400 & 1197 & 1045 & $603^{\circ} \mathrm{w}$ & $435^{b} \mathrm{w}$ \\
\hline$[\mathrm{Ni}(\mathrm{INPP})(\mathrm{Dex})] \cdot 2 \mathrm{H}_{2} \mathrm{O}$ & $3500 \mathrm{~s}$ & $3415 \mathrm{~m}$ & $3322 \mathrm{w}$ & $1600 \mathrm{~s}$ & $1573 \mathrm{~s}$ & $1512 \mathrm{~m}$ & 1395 & 1203 & 1040 & $595^{\circ} \mathrm{w}$ & $425^{\circ} \mathrm{w}$ \\
\hline$[\mathrm{Ni}(\mathrm{INPP})(\mathrm{Fru})] \cdot 2 \mathrm{H}_{2} \mathrm{O}$ & $3495 \mathrm{~m}$ & $3400 \mathrm{~s}$ & $3320 \mathrm{w}$ & $1599 \mathrm{~s}$ & $1574 \mathrm{~m}$ & $1499 \mathrm{~m}$ & 1405 & 1200 & 1050 & $602^{\circ} \mathrm{w}$ & $425^{6} \mathrm{w}$ \\
\hline
\end{tabular}

a where b: saccharides, c: HINPP, s: strong, m: medium, w: weak

Table 4. Thermal data for metal complexes

\begin{tabular}{|l|c|c|c|}
\hline \multirow{2}{*}{ Compound } & \multirow{2}{*}{ Temperature } & \multicolumn{2}{|c|}{ Weight loss due to $\mathrm{H}_{2} \mathrm{O}(\%)$} \\
\cline { 3 - 4 } & Range $\left({ }^{\circ} \mathrm{C}\right)$ & Calculated & served $\quad \mathrm{d}$ \\
\cline { 3 - 4 } & & 8.6 & 8.8 \\
\hline$[\mathrm{Co}(\mathrm{INPP})(\mathrm{Dex})] \cdot 2 \mathrm{H}_{2} \mathrm{O}$ & $106-187$ & 8.6 & 8.3 \\
\hline$[\mathrm{Co}(\mathrm{INPP})(\mathrm{Fru})] \cdot 2 \mathrm{H}_{2} \mathrm{O}$ & $103-178$ & 8.9 & 9.0 \\
\hline$[\mathrm{Ni}(\mathrm{INPP})(\mathrm{Dex})] \cdot 2 \mathrm{H}_{2} \mathrm{O}$ & $101-170$ & & 8.9 \\
\hline$[\mathrm{Ni}(\mathrm{INPP})(\mathrm{Fru})] \cdot 2 \mathrm{H}_{2} \mathrm{O}$ & $119-169$ & & \\
\hline
\end{tabular}

Table 5. Antifungal Activity Data

\begin{tabular}{|c|c|c|c|}
\hline \multirow{2}{*}{ Complex } & \multirow{2}{*}{$\begin{array}{l}\text { Conc. } \\
\text { (ppm) }\end{array}$} & \multicolumn{2}{|c|}{ Inhibition (\%) } \\
\hline & & C. albicans & A. niger \\
\hline \multirow[t]{2}{*}[\mathrm{Co}(\mathrm{INPP})(\mathrm{Dex})]{$\cdot 2 \mathrm{H}_{2} \mathrm{O}$} & 100 & 28 & 40 \\
\hline & 200 & 39 & 52 \\
\hline$[\mathrm{Co}(\mathrm{INPP})(\mathrm{Fru})] \cdot 2 \mathrm{H}_{2} \mathrm{O}$ & 100 & 22 & 45 \\
\hline \multirow{2}{*}[\mathrm{Ni}(\mathrm{INPP})(\mathrm{Dex})]{$\cdot 2 \mathrm{H}_{2} \mathrm{O}$} & $\frac{200}{100}$ & $\begin{array}{l}41 \\
28\end{array}$ & $\begin{array}{l}53 \\
42\end{array}$ \\
\hline & 200 & 42 & 51 \\
\hline \multirow{2}{*}[\mathrm{Ni}(\mathrm{INPP})(\mathrm{Fru})]{$\cdot 2 \mathrm{H}_{2} \mathrm{O}$} & 100 & 25 & 48 \\
\hline & 200 & 48 & 60 \\
\hline \multirow[b]{2}{*}{ HINPP } & 100 & 10 & 11 \\
\hline & 200 & 13 & 12 \\
\hline \multirow[b]{2}{*}{$\mathrm{CoCl}_{2} \cdot 6 \mathrm{H}_{2} \mathrm{O}$} & 100 & 23 & 24 \\
\hline & 200 & 31 & 29 \\
\hline Amphotericin & 100 & 96 & 99 \\
\hline
\end{tabular}

Table 6. Biological activity (MIC $\mu \mathrm{g} / \mathrm{ml}$ ) and $\mathrm{LD}_{50}$ data

\begin{tabular}{|c|c|c|c|c|c|c|c|c|c|}
\hline \multirow[t]{2}{*}{ Compound } & \multicolumn{6}{|c|}{ Antibacterial activity } & \multicolumn{3}{|c|}{$\begin{array}{r}\text { Antifungal activity } \mathrm{LD}_{50} \\
(\mathrm{mg} \cdot \mathrm{kg} \cdot \mathrm{b} . \mathrm{w})\end{array}$} \\
\hline & 1 & 2 & 3 & 4 & 5 & 6 & 7 & 8 & \\
\hline$[\mathrm{Co}(\mathrm{INPP})(\mathrm{Dex})] \cdot 2 \mathrm{H}_{2} \mathrm{O}$ & 100 & 100 & 150 & 100 & 50 & 100 & 100 & 50 & 2342 \\
\hline$[\mathrm{Co}(\mathrm{INPP})(\mathrm{Fru})] \cdot 2 \mathrm{H}_{2} \mathrm{O}$ & 100 & 100 & 100 & 100 & 50 & 100 & 100 & 100 & 2218 \\
\hline$\left[\mathrm{Ni}\right.$ (INPP)(Dex)] $\cdot 2 \mathrm{H}_{2} \mathrm{O}$ & 300 & 100 & 200 & 400 & 100 & 200 & 150 & 200 & 2102 \\
\hline$[\mathrm{Ni}(\mathrm{INPP})(\mathrm{Fru})] \cdot 2 \mathrm{H}_{2} \mathrm{O}$ & 250 & 100 & 150 & 400 & 100 & 200 & 200 & 150 & 2090 \\
\hline Tetracycline & 2.0 & 2.5 & 2.0 & 0.5 & 1.5 & 3.0 & - & - & 6443 \\
\hline Amphotericin & - & - & - & - & - & - & 1.5 & 1.0 & - \\
\hline
\end{tabular}

1. C. diphtheriae; 2. E. coli; 3. S. typhi; 4. S. dysenteriae; 5. S. aureus; 6. V. cholerae; 7. C. albicans and 8. A. niger. 


\section{References:}

[1] Noyori, R. Chiral Metal Complexes as Discriminating Molecular Catalysis. Science. 1990, 248,1194

[2]. Ito, Y. N.; Katsuki, T. Asymmetric Catalysis of New Generation Chiral Metallosalen Complexes. Bull. Chem. Soc. Japan. 1999, 72, 603 .

[3] Hayashi, T.; Tomioka, K.; Yonemitsu, O. Reduction. In Asymmetric Synthesis; Kodansha: Tokyo, $1998 ; 3$

[4] Sharpless, K. B.; Michaelson, R. C. High Stereo- and Regioselectivities in the Transition Metal Catalyzed Epoxidations of Olefinic Alcohols by ter-Butyl Hydroperoxide. J. Am. Chem. Soc. 1973, 95, 6136.

[5] Thakkar, N. V.; Banerji, A. A. A Study of Chiral Mixed Ligand Metal Complexes and Enzymes as Catalysts in Resolution of 1,1'-Binaphthyl-2,2'-diol. J. Ind. Chem. Soc. 1995, 72, 421.

[6] Vagg, R. S.; Williams, P. A. Chiral Mixed Complexes.1. Photochemical Inversion in Tertiary Ru(II) Complexes of Diamines and L-Tryptophen. Inorganica Chimica Acta. 1981, 51, 61.

[7] Hughes, M. N. Coordination Compounds in Biology. In Comprehensive Coordination Chemistry; Wilkinson, G.; Gillard, R. D.; McCleverty, J. A. Eds.; Pergamon Press: Oxford, 1987; Vol. 6, 541.

[8] Thakkar, N. V.; Thakkar, J. R. Synthesis and Characterization of Chiral Mixed Ligand Co(II) Complexes of Isonitrosopropiophenone and Amino Acids. Synth. React. Inorg. Met.-Org. Chem. 2000, 30 (10), 1871.

[9] Aull, J. L.; Daron, H. H.; Friedman, M. E.; Melius, P. Interaction of Anticancar Drugs with Enzymes. In Metal Ions in Biological Systems; Sigel, H. Ed.; Marcel Dekker: New York, 1980; Vol. 11, 337.

[10] Furniss, B. S.; Hannaford, A. J.; Smith, P. W. G.; Tatchell, A. R. Solvents and Reagents. In Vogel's Textbook of Practical Organic Chemistry; $5^{\text {th }}$ Ed.; ELBS, Longman: London, 1989; 395.

[11] Prasad, R. V.; Thakkar, N. V. Decomposition of Hydrogen Peroxide Catalyzed by Cobalt(II) Complexes of Isonitrosopropiophenone Supported on Alumina. Ind. J. Chem. 1994, 33 (A), 861

[12] Vogel, A. I. Complexometric (EDTA) Titrations. In A Textbook of Quantitative Inorganic Analysis; $3^{\text {rd }}$ Ed.; ELBS, Longman Green: London, 1961; 415.

[13] Jeffery, G. H.; Basset, J.; Mendham, J.; Denney, R. C. In Vogel's Textbook of Quantitative Chemical Analysis; $5^{\text {th }}$ Ed.; ELBS, Longman: London, 1991; 257.

[14] Selwood, P. W. Molecular Diamagnetism. In Magnetochemistry; $2^{\text {nd }}$ Ed.; Interscience: New York, $1956 ; 83$.

[15] Hueso-Urena F., Morgeno-Carretero M. N., Salas-Peregrin J. M., Alzarez de Eienfuegos-Lopez G. J. Inorg. Biochem., 1991, 43, 17.[16]. Gould J. C. Brit. Med. Bull., 1960, 16, 26.

[17] Litchfield J. T., Jr. and Wilcoxon F. J. Pharmacol. Exp. Ther., 1949, 96, 99.

[18] Geary, W. J. The Use of Conductivity Measurements in Organic Solvents for the Characterization of Coordination Compounds. Coord. Chem. Rev. 1971, 7 (1), 81.

[19] Lee, J. D. Spectra. In Concise Inorganic Chemistry; $5^{\text {th }}$ Ed., Blackwell Science: London, 1999; 938

[20] Nakamoto, K. Lattice Water and Aquo and Hydroxo Complexes. In Infrared and Raman Spectra of Inorganic and Coordination Compounds, $4^{\text {th }}$ Ed., John-Wiley and Sons: New York, $1986,227$.

[21] Thakkar N. V.; Deshmukh R. G. Indian Journal of Chemistry. 1994, 33A, 224
[22] Howard-Lock, H. E.; Lock, C. J. L. Uses in Therapy. In Comprehensive Coordination Chemistry; Wilkinson, G.; Gillard, R. D.; McCleverty, J. A. Eds.; Pergamon Press: Oxford, 1987; Vol. 6, 755.

[23] Martell, A. E.; Calvin, M. Uses of Chelating Agents. In Chemistry of the Metal Chelate Compounds; Prentice-Hall: New York, 1952; 471.

[24] Madigan, M. T.; Martinko, J. M.; Parker, J. Microbial Growth Control. In Biology of Microorganisms; $8^{\text {th }}$ Ed., Prentice-Hall: New Jersey, 1997; 397. 